\title{
Victorian naturalists in China: science and informal empire
}

\author{
FA-TI FAN*
}

\begin{abstract}
This paper discusses the research of British naturalists in China during the period between the Opium War and the collapse of the Qing dynasty (1839-1911). China was defeated in the Opium War and forced to open treaty ports for trade with the Westerners. The foreign powers, particularly Britain, imposed upon the Qing government treaties, concession leases, favourable trade conditions, legal privileges and so on to reduce its political autonomy. In the shadow of the informal empire, not only did the British have more freedom to travel in China, first at the treaty ports and later in the interior, but they successively established diplomatic, commercial and missionary institutions in dozens of Chinese cities. The most important of them - the British Consular Service, the Chinese Maritime Customs and the Protestant missionary organizations - provided the talent and infrastructure for natural historical research and became networks for scientific information. The research into China's natural history epitomized the characteristics of British research on China in general: it engaged in collecting and circulating an ever-increasing amount of information and aimed at producing 'factual' and 'useful' knowledge about China. The paper modifies current literature on scientific imperialism, which has dealt primarily with the colonial context, by examining the role of nineteenth-century British imperial science in the context of informal empire.
\end{abstract}

There were few noteworthy attempts made by the British before the second half of the eighteenth century to investigate the natural history of China. The activity grew as the British edged out the other European powers and gradually assumed predominance in the China trade around the middle of the eighteenth century. Their increasing presence in China provided the resources and opportunities for sustained research. In 1757 China changed its policy towards Westerners and relegated the trade to one single port, Canton, in south China. This policy continued for almost a century before it was brought to an abrupt end by the Opium War (1839-42). China was defeated and forced to open ports for trade with the Westerners. The British were no longer confined to Canton; they occupied Hong Kong and gained access to five major ports in 1842 . Driven by trade and diplomatic interests, the British, assisted by the French, again bullied Qing China, which was now plagued with domestic problems, including the devastating Taiping Rebellion. After a series of wars, collectively called the Second Opium War (1856-60), and negotiations, China signed treaties that allowed Westerners to set up commercial and diplomatic posts in its interior. The number of the treaty ports would gradually increase to about forty by 1910, scattered across China proper. Most of them were located along the China coast and the Yangzi River - the areas known as the British sphere of influence.

\footnotetext{
* Department of History, State University of New York at Binghamton, Binghamton, NY 13902-6000, USA.

I am grateful to Harold Cook, Victor Hilts, Lynn Nyhart, Robert Richards, two anonymous referees and the Editor of the BJHS for their helpful comments and suggestions.
} 
Not only did the British now have more freedom to travel about the treaty ports and, as the century progressed, in the interior, but they also successively established diplomatic and missionary institutions in many parts of China. New opportunities attracted thousands of merchants, diplomats and missionaries from Britain and other Western nations. ${ }^{1}$ British research into the natural history of China experienced marked changes triggered by these political developments.

During the Canton period, British residents in China were all connected to the East India Company or other trade establishments. The interests, infrastructure and practices of the investigations into China's natural history depended heavily on the China trade. Confined in an urban environment, the trader-naturalists in Canton mobilized their experience and resources in international trade to help them pursue scientific enquiries in the port city, and they managed in this way to collect botanical information and ornamental plants. ${ }^{2}$ The British quest for garden plants in China never diminished. After the middle of the nineteenth century, however, their horticultural focus gradually switched from Chinese gardens, whose treasures seemed to have been exhausted, to wild plants. Meanwhile, greater access to different parts of China and increasing contact with the Chinese opened up new areas of research, one of the most prominent being economic botany. The naturalists' attention was drawn to a wide variety of plant products used by the natives of which they had been unaware. The thought that these investigations might prove to be of great commercial importance added significance to the naturalists' research.

Scholars have not neglected the connections between imperialism and economic botany. It is widely accepted that the British botanical empire, with a nerve system made up of Kew Gardens and the colonial gardens, expanded its tentacles deep into all possible territories in search of plant products of economic value for the Empire. ${ }^{3}$ While this description remains partly valid, the peculiar historical context of the British in China forces us to modify this view. One problem is that extant literature on scientific imperialism has dealt primarily with the colonial context. In the China region, however, the only British colony was the tiny island of Hong Kong and its immediate vicinity. Despite considerable internal problems and external pressures, the Qing government maintained

1 For a survey of Sino-Western relations in the nineteenth century, see John K. Fairbank and Kwang-Ching Liu (eds.), The Cambridge History of China, 15 vols., Cambridge, 1978-80, x. W. H. Medhurst, The Foreigner in Far Cathay, London, 1872, discusses the three major groups of Western residents in China, excluding the working class, and their life in China. See also N. B. Dennys, The Treaty Ports of China and Japan: A Complete Guide to the Open Ports of Those Countries, together with Peking, Yedo, Hongkong and Macao, San Francisco, 1977 [1867]; P. D. Coates, The China Consuls, Oxford, 1988. For the literature on Protestant missionaries to China, see n. 4 below.

2 Fa-ti Fan, 'Science in a Chinese entrepot: British naturalists and their Chinese associates in Old Canton', Osiris (2003), 18 (forthcoming).

3 E.g. Lucile Brockway, Science and Colonial Expansion: The Role of the British Royal Botanical Gardens, New York, 1979; Donal P. McCracken, Gardens of Empire: Botanical Institutions of the Victorian British Empire, London, 1997; Richard Grove, Green Imperialism: Colonial Expansion, Tropical Island Edens and the Origins of Environmentalism, 1600-1800, Cambridge, 1995; Richard Drayton, Nature's Government: Science, Imperial Britain, and the 'Improvement' of the World, New Haven, 2000; Daniel Headrick, The Tentacles of Progress: Technological Transfer in the Age of Imperialism, 1850-1940, Oxford, 1988, 209-58; William Kelleher Storey, Science and Power in Colonial Mauritius, Rochester, 1997. 
a fairly high level of political autonomy. Here a modified concept of 'informal empire' may be introduced as a heuristic device to describe British scientific imperialism in China. The concept originally refers to the economic control, often in the name of free trade, that an imperial power exercised beyond its formal territories. For our purpose, we shall not focus so exclusively on trade or the economic aspect of imperialism - though they remain important components of our historical interpretation - but shall venture into less explored topics, such as informal empire and its relations to networks of scientists, political economy of knowledge and the dynamics of cultural contact.

The foreign imperial powers, particularly Britain, extorted from the Qing government treaties, concession leases, favourable trade relations, extraterritoriality and other legal privileges, by persuasion, pressure and gunboat diplomacy. British presence in China owed much to its imperial domination, and that historical condition helped shape the aims, means and possibilities for scientific research. In this case, the diplomatic and other institutions whose missions were not primarily scientific proved to be instrumental in British scientific imperialism in China. The major establishments that took part in the natural historical research were the British Consular Service in China, the Chinese Maritime Customs, the Protestant missionaries and the Hong Kong Botanic Gardens. ${ }^{4}$ The British Consular Service in China was an official diplomatic institution. Its consulates could be found in most of the treaty ports, and together they formed the largest consular network in the world. ${ }^{5}$ The Chinese Maritime Customs was a department of the Chinese government, but it fell under British influence. It was even more extensive than the British Consular Service in China. Only by bringing these institutions to the centre of the historiographic stage can we understand the scale, purpose and practice of the British botanical empire in China.

The naturalists, who were widely separated in different provinces, needed networks for gathering, analysing and distributing information and specimens among themselves. This problem of the naturalists, however, only reflected a general concern of Westerners in China. Whether they were missionaries, merchants or diplomats, they all found themselves involved in collecting and circulating an ever-increasing amount of information about the 'mysterious' empire and its 'singular' people. Relevant, accurate and sufficient information about China seemed vital for many reasons, and the result was the emergence of institutions that made the collection and diffusion of data a principal objective. All of this activity worked together with the efforts of ' unveiling' China, which was motivated by practical considerations as well as by an orientalist desire to explore the vast Middle Kingdom and to produce 'objective' factual knowledge about it.

The intensification of British imperialism in the China region that occurred in the wake of the Opium War added another dimension to research in China. Collecting and

4 For basic accounts of these institutions, see Coates, op. cit. (1); Stanley Wright, Hart and the Chinese Customs, Belfast, 1950; K. S. Latourette, A History of Christian Missions in China, Taipei, 1966 [1929]; Paul Cohen, 'Christian missions and their impact to 1900', in Fairbank and Liu, op. cit. (1), 543-90; D. A. Griffiths and S. P. Lau, 'The Hong Kong Botanical Gardens: a historical overview', Journal of the Hong Kong Branch of the Royal Asiatic Society (1986), 26, 55-77.

5 Jürgen Ostenhammel, 'Britain and China', in The Oxford History of The British Empire: The Nineteenth Century (ed. Andrew Porter), Oxford, 1999, 146-69, 156. 
possessing 'useful' information about China laid the groundwork for British imperial surveillance and the exploitation of economic opportunities. The British Consular Service in China, so enormous as to outstrip immediate relevance for trade, was not merely 'an expensive luxury', as has recently been suggested. ${ }^{6}$ It was frequently mobilized for the accumulation of intelligence or 'facts'; it served a critical function in British informal empire. The research into China's natural history epitomized the characteristics of British research on China in general: it aimed at producing 'factual' and 'useful' knowledge about China - in this case, its natural products. Consequently, the naturalists were able to utilize the non-scientific institutions they belonged to for natural historical research. ${ }^{7}$ One can almost say that the British botanical empire in China rode piggyback on the existing institutions.

However, there were real constraints on British informal empire in China, especially beyond the coast, the treaty ports, and the Yangzi River. Any study of British scientific imperialism in China must acknowledge this political reality and its implications for scientific research. The naturalists frequently found themselves lacking the ability to coerce the Chinese into providing information; in such cases, the mode of collecting information was one of negotiation, which did not always go in favour of the naturalists. It is therefore necessary to examine the tactics, meanings and power relations involved in these negotiations since they set the framework within which the British collected information and data in China. The ideology and practice of collecting information about China, as we shall see, were interconnected with scientific imperialism and the naturalists' belief in the cognitive superiority of the modern Western tradition of factual knowledge.

\section{Hong Kong Botanic Gardens}

As the British Empire grew, Kew Gardens and its satellite gardens in the colonies formed a network that circulated living plants, specimens and information across the globe. They also directly participated in many imperial and colonial enterprises that required the development of plantations of crops of economic value, such as tea, sisal and cinchona trees, in the colonies. In the China area, the British had only one colonial botanical garden, the Hong Kong Botanic Gardens, which maintained close ties with Kew Gardens and worked towards goals similar to those of other colonial gardens. For various reasons, it never became the central institution of British research into the flora or the economic botany of China. Since colonial gardens had been crucial to the building of the British

6 Ostenhammel, op. cit. (5), 156.

7 On information technologies and imperialism and colonialism, see e.g. C. A. Bayly's Empire of Information: Intelligence Gathering and Social Communication in India, 1780-1870, New York, 1996; Matthew H. Edney, Mapping an Empire: The Geographical Construction of British India, 1765-1843, Chicago, 1997; Richard Drayton, 'Knowledge and Empire', in The Oxford History of the British Empire: Eighteenth Century (ed. P. J. Marshall), Oxford, 1998, 321-52; David Ludden, 'Orientalist empiricism: transformations of colonial knowledge', in Orientalism and the Postcolonial Predicament (ed. Carol A. Breckenridge and Peter van der Veer), Philadelphia, 1993, 250-78; Arjun Appadurai, 'Number in the colonial imagination', in ibid., 314-39; Deepak Kumar, Science and the Raj, 1857-1905, Delhi, 1997, Chapter 3. 
botanical empire in many other areas, the disappointing accomplishment of the Hong Kong Botanic Gardens needs further explanation. The example will also usefully remind us of the tensions, conflicts and competitions that different imperial institutions, despite their intended cooperation, sometimes experienced with each other. The British Empire was not a coherent, smooth-running whole.

The British acquired Hong Kong as part of their booty from the Opium War. In its first colonial years, Hong Kong gained notoriety for its devastating tropical climate which was thought to be responsible for the high disease and death rate among the British troops stationed there. 'During July August \& September [1850], we buried about 300 men', a soldier lamented. ${ }^{8}$ That took care of a quarter of the total number of the troops. In hope of improving the climate, the colonial government of Hong Kong therefore decided to afforest the island by planting large numbers of shade trees. In this, they followed a practice that was common on many tropical colonial islands. ${ }^{9}$ The Hong Kong government also wanted to establish a nice garden for the British residents. As a new colony, Hong Kong had no fine gardens to boast of, and its British residents could only admire the gardens of St Helena, Mauritius, Calcutta and Ceylon. Through the Colonial Office in London, the Hong Kong Government sought help from Joseph Hooker, Director of Kew, by asking him to recommend a good gardener who could take the responsibility of developing and superintending the projected garden. Charles Ford, a practising gardener who had served at several private and public gardens in Britain, was selected to fill the position. He arrived in Hong Kong in $1871 .^{10}$

In spite of this promising start, Ford's career soon suffered the same difficulties in which many superintendents of colonial gardens found themselves, sandwiched between colonial governments and Kew Gardens. Ford's responsibilities included not only developing the Hong Kong Botanic Gardens, but also the afforestation of the island. Indeed, on his retirement, when Ford looked back at his career of thirty-one years in Hong Kong, he regarded afforesting the island, instead of developing the Gardens, as his 'magnum opus'. ${ }^{11}$ To the Hong Kong government, Ford's first duty in managing the Gardens was to create and maintain a beautiful public garden for Westerners in Hong Kong. It would be an exaggeration to compare Ford to someone like Ferdinand von Mueller, a noted botanist and Director of the Melbourne Botanic Gardens, whose enthusiasm for scientific research led him into serious conflicts with local dignitaries who cared more about colourful flowers than dried specimens. ${ }^{12}$ Nevertheless Ford, like Mueller, frequently complained to Hooker about his difficult situation. So much of his time was spent on planting trees and growing flowers that botanical research became a rare occasion,

8 Keith Sinclair (ed.), A Soldier's View of Empire: The Reminiscences of James Bodell, 1831-92, London, $1982,58$.

9 Grove, op. cit. (3), Chapters 5-8.

10 Kew Gardens Archives (henceforth 'Kew'), Misc. Reports, 4.41, Hong Kong Botanic Gardens, 1870-1915, ff. 2-19.

11 Kew, Misc. Reports, 4.41, Hong Kong, Botanic Gardens, 1870-1915, ff. 28-30; Public Records Office (Hong Kong), CO 129/189, 129/190.

12 Edward Kynaston, A Man on Edge: A Life of Baron Sir Ferdinand von Mueller, London, 1981, 269-73, 280-92. 
a luxury. A particularly unsympathetic governor was said to care little about the Gardens other than demanding a regular supply of vegetables for the dinner table of 'his tremendous family'. ${ }^{3}$

The Hong Kong government was not simply being backward, myopic or vulgar although that seems to have been the assessment of Ford and his scientific friends. ${ }^{14}$ The administration was convinced that no botanical research, even if related to economic botany, would profit the colony. ${ }^{15}$ It saw no possibility or reason to develop plantations of any kind on a minute mountainous island whose economic prospects rested entirely on trade, shipping and commerce. It seemed clear that any fruits of botanical research sponsored by Hong Kong would always go to some other British colonies. To the Hong Kong government, the Gardens were simply a 'public recreation ground' where Western residents could stroll around after a day's work and where concerts could be performed in summer. ${ }^{16}$ It thus had neither a scientific nor an economic function.

The view taken by the Hong Kong government on its botanical garden contradicted that of Kew Gardens. Because the Botanical Gardens officially fell under the administration of the Hong Kong government, Kew Gardens had only limited control over its management. In order to exert an influence, Joseph Hooker had to pull strings through his connections to the Colonial Office (in London), which supervised all the colonial governments, and through his patronage of Ford. Hooker had a clear vision of what the colonial Gardens should be like, and he expounded the idea in a letter to the Colonial Office. ${ }^{17}$ Hong Kong, according to Hooker, occupied a unique position in discovering 'the economic and scientifically interesting vegetable productions of China'. ${ }^{18}$ The notion that the Gardens were simply a pleasure ground ran against Hooker's 'idea of a Botanical Garden in any sense' ${ }^{19}$ On the contrary, the Hong Kong government, he argued, should allow Ford to make occasional expeditions and encourage him to transform the Gardens into 'the channel of communication for all matters of botanical interest connected with China' ${ }^{20}$ In a separate letter, Hooker pointed out to Ford that little was known about the 'indigenous vegetation of South East Asia and of the useful application of its plants' ${ }^{21} \mathrm{He}$ instructed Ford to set up a herbarium and to visit the accessible places in China 'for the purpose of collecting plants and of obtaining information about the sources of the drugs, woods, \&c.' that were used by the Chinese. ${ }^{22}$ Hooker further noted that botanical research of this kind was beyond the ability of any individual or institute, and he suggested that Ford 'enlist the co-operation of traders, merchant captains, sea surgeons and others' in his

13 Kew, Chinese and Japanese Letters, 151 (850); Kew, Misc. Reports, 4.41, Hong Kong, Botanic Gardens, 1870-1915, ff. 67-8.

14 E.g. Kew, Chinese and Japanese Letters, 150 (546), (550), (551), (850).

15 Kew, Misc. Reports, 4.41, Hong Kong, Botanic Gardens, 1870-1915, ff. 40-3.

16 Kew, Chinese and Japanese Letters, 150 (551), (198-9).

17 Kew, Misc. Reports, 4.41, Hong Kong Botanic Gardens, 1870-1915, ff. 108.

18 Kew, op. cit. (17).

19 Kew, op. cit. (17).

$20 \mathrm{Kew}$, op. cit. (17).

21 Kew, Misc. Reports, 4.41, Hong Kong, Botanic Gardens, 1870-1915, ff. 109-10.

22 Kew, op. cit. (21). 
enquiries. ${ }^{23}$ In an unequivocal tone, Hooker reminded Ford to make the Botanic Gardens the headquarters of the investigation into the flora of China, 'whether scientific or simply utilitarian', ${ }^{24}$

With these instructions from London, Ford's official responsibilities now included exploration and scientific correspondence, besides gardening and afforestation. ${ }^{25} \mathrm{He}$ was able to set up a modest herbarium, together with a small library of botanical and gardening books. ${ }^{26}$ Hooker's goal, however, was never fully realized. In spite of Hooker's pleadings, Ford still had little time and few opportunities for botanical research. ${ }^{27}$ Ford's somewhat passive personality ('a quiet modest young man', according to a friendly observer) also prevented him from confronting the Hong Kong government, whose support for scientific research remained more nominal than material. ${ }^{28}$

Another reason why Ford and his establishment did not become the hub of botanical correspondence in China was that one already existed. Henry Hance of the Consular Service had been studying the flora of China since the 1840s, and he had long established a vast personal herbarium, a wide network of botanical information and a well-deserved reputation as an authority on Chinese plants. Indeed, Ford learned his basics of botany identifying plants, preserving specimens and so on - from Hance and constantly consulted him on botanical matters. ${ }^{29}$ If anything, Ford was incorporated into Hance's already extensive botanical network rather than the other way around. Even when Hance died in 1886, Ford was unable to fill the gap. How did a consular officer at an inconsequential post acquire so much botanical authority and resources? Hance's scientific career illustrates the scale, influence and effectiveness of the network of scientific data forged by Western residents in China and leads us to consider some of the salient characteristics of British scientific imperialism in China.

\section{Henry Fletcher Hance}

Except for brief stints in Amoy and Canton, Henry Fletcher Hance, Vice-Consul at Whampoa, was trapped in that minor post and had no chance of promotion because he knew no Chinese. ${ }^{30}$ After completing his education in continental Europe, he came to China with his father in 1844, entered the Civil Service a few years later, and returned

23 Kew, op. cit. (21).

$24 \mathrm{Kew}$, op. cit. (21), original emphasis. It is worth noting that Hooker and his scientific allies had just won a bitter controversy with the British government about the primary objective of Kew Gardens. The controversy was more or less parallel to and must have had some impact on the controversy concerning the Hong Kong Botanic Gardens. See, e.g., Ray Desmond, Kew: The History of the Royal Botanical Gardens, London, 1995, 223-50; R. M. MacLeod. 'The Ayrton incident: a commentary on the relations of science and government in England, 1870-73', in Science and Values (ed. Arnold Thackray and Everett Mendelsohn), New York, 1974, $45-78$.

25 Kew, Misc. Reports, 4.41, Hong Kong Botanic Gardens, 1870-1915, f. 111.

26 Public Records Office (Hong Kong), CO 129/217, 129/218.

27 Kew, Chinese and Japanese Letters, 150 (273-4). See also 150 (228-9), (247), (399-401).

28 Kew, Chinese and Japanese Letters, 150 (546), (550).

29 Kew, Chinese and Japanese Letters, 150 (193), (239-40), (268-69); Kew, Misc. Reports, 4.41, Hong

Kong, Botanic Gardens, 1870-1915, ff. 95-6.

30 Coates, op. cit. (1), 201-3. Kew, Misc. Report, 4.4, China, Hance, 2-4. 
to England over 1851 and 1852 for a visit. By then, he had already developed a passion for botany. ${ }^{31}$ He met William Hooker, Director of Kew Gardens, and would become William and Joseph Hooker's chief correspondent in China. On New Year's Eve of 1851, Hance proposed to his fiancée by a lake in Kew Gardens and subsequently brought her to China. ${ }^{32}$ They soon had a large family. Financially stressed, Hance never managed to visit England again. He died thirty years later a world authority on Chinese plants. ${ }^{33}$

Hance was a taxonomist and never did any notable fieldwork, except during a sojourn in Amoy in the autumn of $1857 . .^{34}$ In many ways, the location of his post was the worst fieldwork site one could have in China, for the whole Canton area was denuded of wild vegetation and the place had been worked thoroughly. ${ }^{35}$ Yet Hance realized that the flora of much of China remained unexplored, and that collecting specimens and information was critical to research. Driven by his zeal for botany, Hance soon built an extensive network of scientific correspondents across China, with his colleagues in the Consular Service as his core associates. Although Hance was eccentric, forthright and probably intemperate (qualities that must have hurt his professional career), he was also kind, generous and principled. ${ }^{36} \mathrm{He}$ was scholarly ('a good Latin and French scholar', according to his colleagues) and owned a well-stocked personal library. ${ }^{37}$ The critical period of his networking in China was probably in the late 1840s and early 1850s when new members of the Consular Service still often stopped in Hong Kong and Canton for a few months to learn the Chinese language while waiting to be assigned to their posts. Hance impressed them with his learning and kindled their interest in collecting botanical specimens, if not necessarily in studying botany itself. As his enthusiasm for botany became widely known, his network of scientific data in China expanded very much on its own. ${ }^{38}$

British naturalists in China respected Hance greatly. Robert Swinhoe, the foremost British zoologist in China, and Hance were colleagues, friends and fellow naturalists. ${ }^{39}$ William Hancock, botanist and a Chinese Customs officer, told Joseph Hooker that '[my] personal regard for Dr Hance, (independent of my admiration for him as a

31 Apparently, he had learned some botany before coming to China. See DNB, vol. 8, 1156.

32 Kew, Chinese and Japanese Letters, 150 (531).

33 Basic biographic facts of Hance can be found in Gardeners Chronicle, 14 August 1886, 218-19; Hongkong Daily Press, 26 and 28 June 1886; E. Bretschneider, History of European Botanical Discoveries in China, 2 vols., Leipzig, 1962 [1898], 365-70, 632-52; DNB, vol. 8, 1156-7. He received an honorary Ph.D. from the University of Giessen (Germany) in 1849.

34 Kew, Bentham Correspondence, 5 (1768-9).

35 See, for example, George Bentham, Florae Hongkongensis: A Description of the Flowering Plants and Ferns of the Island of Hongkong, London, 1861, and Henry Hance's 'Supplement' (1871).

36 Comments on Hance's personality can be found in, for example, School of Oriental and African Studies (henceforth 'SOAS'), Chaloner Alabaster Papers, MS 380451/2, entry under 2 January; MS 380451/3, entry under 1 June; E. H. Parker, 'Henry Fletcher Hance', Journal of the North China Branch of the Royal Asiatic Society (1886), n.s., 21, 309-13. See also Francis Forbes's letter to J. D. Hooker in Kew, Misc. Reports, 4.4, China, Hance, ff. 23-5, and Thomas Wade's letter in the same volume, f. 26.

37 Kew, Misc. Reports, 4.4, China, Hance, ff. 2-4, ff. 127-37.

38 Kew, Bentham Correspondence, 5 (1768-9), (1770-2), (1773-5), (1780-6), (1790).

39 Bretschneider, op. cit. (33), 661-78. See also Hance's letters to Swinhoe in Kew, Kew Collectors IV, Richard Oldham (120), (122). 
botanist), is such, that I preserve with care all his letters' ${ }^{40}$ When Theophilus Sampson, Hance's botanical sidekick, travelled extensively in the province of Guangdong as an agent for the infamous coolie trade, he also collected for Hance. ${ }^{41}$ Edward H. Parker, a consular colleague in Canton, studied botany with Hance and never lost his interest in the subject. ${ }^{42}$ Hance influenced deeply these and many other people who came in contact with him. He was the botanical authority in China and received specimens, questions and volunteer assistance from everywhere. His dedication to botany earned him wide respect even among non-British Westerners in China, and they, too, corresponded with him and sent him specimens. Encouraged by him, Francis B. Forbes, an American merchant, launched a project of cataloguing all Chinese plants then known to science. The project, soon taken over by the British, would culminate in the authoritative series of Index Florae Sinensis (1886-1905). ${ }^{43}$ Emil Bretschneider, Physician to the Russian Legation in Beijing and a man of wide learning, became a good friend of Hance on the basis of their common interest in botany and their respect for each other's scholarship. ${ }^{44}$

Hance thus received plants from his correspondents all over China and built up a splendid personal herbarium comparable to major research institutes in Europe in its collection of Chinese plants, which included numerous type specimens. ${ }^{45} \mathrm{His}$ wife assiduously arranged and labelled the specimens. ${ }^{46}$ Hance's network of correspondence was global, reaching Asa Gray in the United States, Carl Maximowicz in St Petersburg and many major botanists in Belgium, Germany, France and Britain. However, he was particularly closely connected to Kew Gardens, sending them the best duplicates of his Chinese plants, and he regarded Joseph Hooker and George Bentham as his principal botanical friends in Britain, who reciprocated this confidence with efforts to obtain promotion for him as well as routine scientific assistance. ${ }^{47}$

Hance relied little on research centres in Europe for Chinese plants, for his personal network of correspondents in China brought him numerous specimens and gave him better access to, and claim for, authority on the plants in south and east China than did any botanists in Europe. Indeed, he was a major source of Chinese plant specimens for research institutes in Europe, using the many duplicates received from his network to

$40 \mathrm{Kew}$, Chinese and Japanese Letters, 151 (475).

41 See e.g. Bretschneider, op. cit. (33), 652-61; Hance's letters to J. D. Hooker, Kew, Chinese and Japanese Letters 151 (493), (514-15), (519); Sampson to Thiselton-Dyer, Kew, Chinese and Japanese Letters 151 (928); Hance to Swinhoe, Kew, Kew Collectors IV, Oldham (120). See also Hance's letters to Daniel Hanbury in Royal Pharmaceutical Society (henceforth 'RPS'): Hanbury Papers, P313 [3], [32].

42 See E. H. Parker, 'Henry Fletcher Hance', Journal of the North China Branch of the Royal Asiatic Society (1886), n.s., 21, 309-13.

43 W. T. Thiselton-Dyer, 'Historical notes', in F. B. Forbes and W. B. Hemsley, Index Florae Sinensis (1905), pp. v-xi. See also Kew, Misc. Reports, 4.4, China, Index Florae Sinensis, 1883-1905.

44 E. Bretschneider, On Chinese Silkworm Trees, Peking, 1881, 1; idem, Notes on Some Botanical Questions Connected with the Export Trade of China, Peking, 1880, 14. See also Hance's letters in RPS, Hanbury Papers, PH313 [20], PH313 [24].

45 Kew, Misc. Reports, 4.4, China, Hance, ff. 11, 75, 87.

46 Kew, Chinese and Japanese Letters, 151 (531).

47 On the efforts to obtain promotion for Hance, see Kew, Misc. Reports, 4.4, China, Hance, 1882-8, ff. 1-5, $23-5,49$. 
exchange with them specimens for taxonomic comparison. He published more than two hundred papers on Chinese plants and related subjects. Hance's earnest personality sometimes drove him a little too far, and he did not hesitate to challenge the authority of the great and powerful. Consulted by William Hooker, Hance reasoned forcefully with the grand old man about his plan and execution of sending collectors to East Asia, trying to convince him that he had picked the wrong man and that his design and management of the plan were flawed. ${ }^{48}$ Hance's confidence arose from his familiarity with the flora and situation of China, a confidence shared by Bretschneider and other competent naturalists in China. Bretschneider once became annoyed by William Thiselton-Dyer, then Director of Kew Gardens, for doubting his (and Hance's) authority on a matter concerning Chinese plants. ${ }^{49}$ During a dispute over specimens a few years earlier, Thiselton-Dyer faulted Ford for sharing his unique collections with Hance before sending them to Kew; he also accused Hance of infringing the property right of Kew thereby and of trying to secure a monopoly on the botany of China.$^{50}$ All scientific institutes carefully guarded their property and intellectual rights. They wanted to own good specimens of new plants, especially type specimens, and to publish reports on the novelties. Hance and Kew, however, had previously reached an agreement that to take advantage of the freshness of the specimens he could describe Ford's new plants. Convinced of his own innocence, Hance vigorously defended himself and indeed reprimanded Thiselton-Dyer as though the Assistant Director of Kew was merely an erring junior colleague. ${ }^{51}$

The scientific career of Hance demonstrates the possibility for naturalists to develop powerful and extensive scientific networks on the institutional base of non-scientific organizations in China. Hance had no resources other than his energies and personal qualities, by which alone he mobilized his friends and colleagues in the Consular Service and other organizations to collect scientific data for him. But his success also depended on the particular nature of the social world of British residents in China and of the diplomatic and other organizations. It was a small world despite its geographical range; information and influence could be transmitted quickly and broadly. Everyone knew that Dr Hance welcomed specimens and that he never refused to offer help with botanical matters. Specimens poured in from all directions to Hance's house in the tiny town, where he, a frustrated Consular officer fond of drinking, reading and children, carefully identified the plants and introduced them into the world of botany.

\section{Institutions of informal empire}

Although the cohort of Hance's scientific correspondents in China consisted of his colleagues in the British Consular Service, two other institutions in China - the Chinese Imperial Maritime Customs Service and the Protestant missionary organizations - also provided talent and infrastructure for natural historical research. The two government services employed large numbers of British officers. Between the 1840s and the 1890s, the

48 Kew, Directors Correspondence, Chinese Letters, 57 (73)-(77).

49 Kew, Misc. Reports, 4.4, China, Economic Products, I, ff. 229-30.

$50 \mathrm{Kew}$, Chinese and Japanese Letters, 150 (574-5). See also Ford's letters to Kew, 150 (217-18), 150 (221).

$51 \mathrm{Kew}$, Chinese and Japanese Letters, 150 (574-5). 
British Consular Service in China employed more than two hundred officers, excluding lesser employees and the many Chinese writers. By 1880 they had opened consular establishments in more than twenty cities. ${ }^{52}$ The other political institution, the Chinese Customs, was actually a government agency of China, founded in 1854 to run the maritime customs at the treaty ports. ${ }^{53}$ Under British pressure, the actual management of the organization went into British hands from the very beginning. Its officers, from the inspector-general down, were mostly British, but also included other Europeans and Americans. In 1896 the Customs had 679 Western employees, of whom 374 were British, 83 German, 51 American and so on. ${ }^{54}$ Both services adopted similar methods of recruiting new members after about 1860 . They selected well-educated British and Irish young men (and in the case of the Chinese Customs, continental Europeans and Americans as well) through examinations. ${ }^{55}$ Newly recruited members, approximately 20 years of age, spent their first months in China cramming in the language before being sent to the various stations. Each service also had scores of Chinese clerks on the staff as writers. ${ }^{\mathbf{5 6}}$

These non-scientific organizations outstripped any scientific bodies in supplying talent for research into the natural history of China. Only French missionaries, who had their own network and enterprise, and Russians, who had unique access to the northern and north-western parts of the Chinese Empire, contributed as much. ${ }^{57}$ Energetic and educated, junior members of the British Consular Service and of the Chinese Maritime Customs could make ideal naturalists. They had studied in public schools and learned rudimentary science; some even had university degrees. ${ }^{58}$ Their positions also provided them with means and opportunities for gathering scientific data. Some of them had already acquired an interest in natural history at home: Robert Swinhoe, William Hancock, Chaloner Alabaster, G. M. H. Playfair and Edward C. Bowra belonged to this category. ${ }^{59}$ The majority took up the hobby in China. They were excited by the vision of infinite opportunities in a vast empire whose flora and fauna were scarcely known to

52 The consular officers and the consular establishments in China are conveniently listed in Coates, op. cit. (1), 489-90.

53 Stanley F. Wright, op. cit. (4) and the explanatory essays in Katherine F. Brunner, John K. Fairbank and Richard J. Smith (eds.), Entering China's Service: Robert Hart's Journals, 1854-1863, Cambridge, MA, 1986, and idem, Robert Hart and China's Early Modernization: Robert Hart's Journals, 1863 -1866, Cambridge, MA, 1991.

54 Wu Chouyi, Qingmo Shanghai zujie shehui (The Society of Foreign Concessions in Late Qing Shanghai), Taipei, 1978, 55.

55 Coates, op. cit. (1), 76-80; Wright, op. cit. (4), 260-71. See also Hart's journals cited above and John King Fairbank, K. F. Bruner and E. M. Matheson (eds.), The I. G. in Peking: Letters of Robert Hart, Chinese Maritime Customs, 1868-1907, 2 vols., Cambridge, MA, 1975.

56 Robert Fynn, British Consuls Abroad: Their Origin, Rank and Privileges, Duties, Jurisdiction and Emoluments, London, 1846, 30-1 describes the basic personnel structure of the China consulates, which would greatly expand in the rest of the century.

57 As a contemporary witness, Bretschneider knew well this fact. See Bretschneider, op. cit. (33), 631.

58 One of the criteria for the entrants was 'a public-school and something beyond'. See Coates, op. cit. (1), 78. On botany in school education, see e.g. David Layton, Science and the People: The Origins of the School Science Curriculum in England, London, 1973, Chapter 3.

59 Coates, op. cit. (1), 98 ; SOAS, Chaloner Alabaster Papers, Diary 1, MS 380451/1, 18, 19, 28 October 1855, etc.; Kew, Chinese and Japanese Letters, 151 (875-9); SOAS, Bowra papers, MS English, 201813, Box 2, No. 7, Diary for 1863, July 18. 
Westerners. The more enthusiastic incited their friends and colleagues. While stationed in Fujian, southern China, Robert Swinhoe guided his consular colleague H. F. W. Holt to ornithology and lent him a Chinese taxidermist. ${ }^{60}$ Augustine Henry, a Customs officer and a zealous botanical collector, encouraged his colleague Hosea Morse and Morse's wife to pursue botanical collecting. ${ }^{61}$

Although few of these naturalist-collectors enjoyed a scientific reputation, they had much to gain in the pursuit. They collected for fun, for curiosity, for self-improvement, for ambition, for the intellectual satisfaction of making a contribution to science, for the good feeling of having a respectable hobby; and sometimes they were requested by friends or ordered by superiors to investigate certain products of nature. Henry began botanizing in Ichang (Yichang), central China, partly out of boredom. The life of Westerners in minor treaty ports could be depressingly routine and unexciting. Collecting specimens joined tennis, card games and hunting as regular pastimes. ${ }^{62}$ Some of the young diplomats were typical Victorian mountaineers and loved nature. William Hancock had climbed high mountains in Europe and the Americas, and collected along the way botanical specimens for Joseph Hooker, who was himself no faintheart and had breathed the thin air on top of the Himalayas. ${ }^{63}$ While in China, Hancock collected for Hance and Hooker and, true to the Victorian spirit of 'muscular imperialism' and following the example of Swinhoe, he visited the alleged headhunting tribes of Taiwanese aborigines. ${ }^{64}$

Overall, the administrations of the Chinese Customs and the British Consular Service supported the scientific activities of their members as long as the regular official work did not suffer as a result. Yet, due to the different political natures of the two establishments, they held different official positions with regard to assisting British scientific organizations in research matters. Robert Hart, Inspector-General of the Chinese Maritime Customs, instructed the commissioners of customs to investigate a series of subjects relating to fisheries, medicine and economic botany, and he was respected by Western residents in China for his 'enlightened' support of science. ${ }^{65}$ But he never offered much

60 Robert Swinhoe, 'Ornithological ramble in Foochow, in December 1861', Ibis (1862), 4, 257.

61 Kew, Augustine Henry, Letters to H. B. Morse, 1893-1909, ff. 3-5; 7-9; 10-12; 17-18; 19; 29 ; 34-5. See also John King Fairbank, Martha Henderson Coolidge and Richard J. Smith, H. B. Morse: Customs Commissioner and Historians of China, Lexington, KY, 1995, 117-18.

62 These were daily routines of Augustine Henry and his colleagues in Ichang. See his diaries in National Botanical Garden, Ireland (henceforth 'NBG'), Augustine Henry papers, 582.095. Henry's other motivation for studying botany was his growing interest in Chinese materia medica.

63 Kew, Chinese and Japanese Letters, 151 (470-2). See also 151 (475), (476), (481). On Hooker's scientific travels, see Ray Desmond, Sir Joseph Dalton Hooker: Traveller and Plant Collector, Woodbridge, 1999. For science and mountaineering, see Bruce Hevly, 'The heroic science of glacier motion', in Osiris (1996), 11, 6686. Peter Hansen discusses mountaineering and masculine imperialism in his 'Albert Smith, the Alpine Club, and the invention of mountaineering in mid-Victorian Britain', Journal of British Studies (1995), 34, 300-24.

64 Hancock's intense interest in natural history can be seen in his 'Notes on the physical geography, flora, fauna, etc., of northern Formosa, with comparisons between that district and Hainan and other parts of China', which was attached to his Tamsui Trade Report for the Year 1881, Tamsui, 1882. Ibid., 31-8, describes his encounter with the aborigines. Robert Swinhoe, Notes on the Ethnology of Formosa, London, 1863.

$65 \mathrm{Kew}$, Chinese and Japanese Letters, 151 (471). See also 'Shanghai Museum, report of the curator for the Year 1880', Journal of the North China Branch of the Royal Asiatic Society (1880), n.s., 15, p. xxiv; Bretschneider, op. cit. (33), 631. In addition to the annual reports from the various ports, the Chinese Maritime Customs also published special series concerning scientific subjects, e.g. List of Chinese Medicines. China. 
official assistance to Kew Gardens, in spite of Kew's direct requests. Impressed with Augustine Henry's collections, Thiselton-Dyer suggested that Hart grant the young man a long leave for botanical fieldwork. To his disappointment, however, Henry received only a three-month extension of his regular summer vacation. ${ }^{66}$ Hart did not explain why he soft-pedalled any cooperation with Kew Gardens; he might have found it problematic and unjustifiable to submit to a British organization the resources and facilities of a branch of the Chinese government. ${ }^{67}$ Nevertheless, he did permit indirect assistance and private actions. Many years later, after taking stations in Hainan, Taiwan and Yunnan, Henry suspected that he had been posted to these remote and little-explored places because of his interest in botany. ${ }^{68}$ And the ornithologist John David Digues La Touche also obtained from Hart leave to do fieldwork in the Wuyi mountains (south-east China), for which a legless lizard discovered there was dedicated to him. ${ }^{69}$

The matter was very different with the British Consular Service in China. The establishment belonged to the British government and felt the full strength of Hooker's political muscle. Kew Gardens applied their requests directly to the Foreign Office in London, which then passed them on to the Consular Service in China. The Service's headquarters in Beijing complied accordingly and commanded HM Consuls in China to execute the orders. Most of the investigations concerned economic botany. Since some of the Consular officers were interested in natural history and had privately been corresponding with Kew Gardens, they often went the extra mile in enquiring into the matters for Kew. ${ }^{70}$

\section{Scientific networks}

The research modes of naturalists whose reason for being in China was not scientific largely depended on, and were determined by, their duties as civil servants, missionaries or merchants. Both the Consular Service and the Maritime Customs, for example, reshuffled their staff very often, and their officers were transferred from station to station

Imperial Maritime Customs, III, Miscellaneous Series, No. 17, Shanghai, The Statistical Department of the Inspector General of Customs, 1889; An Epitome of the Reports of the Medical Officers to the Chinese Imperial Maritime Customs Service from 1871 to 1882, London, 1884; Silk, China. Imperial Maritime Customs, II. Special Series: No. 3, Shanghai, Department of the Inspectorate General, 1881; Special Catalogue of the Chinese Collection of Exhibits for the International Fisheries Exhibition, London, 1883, Shanghai, Statistical Department of the Inspector General, 1883.

66 Kew, Chinese and Japanese Letters, 151 (596-7), (621), (627), (629).

67 Hart was quite conscientious about his role as an employee of the Chinese government and required his subordinates to be the same, though conflicting feelings and interests were sometimes inevitable. For the details, see Hart's journals and letters cited above and Wright, op. cit. (4), 261-2.

68 Henry to C. S. Sargent, 10 May 1899, NBG, Augustine Henry Papers, in the file 'C. S. Sargent'.

69 Natural History Museum of London (henceforth 'NHML'), Curator of Mammals, Correspondence, DF232/6, f. 512; G. A. Boulenger, 'On a collection of reptiles and batrachians made by Mr. J. D. La Touche in N.W. Fokien, China', Proceedings of the Zoological Society (1899), 161.

70 Copies of Kew's applications to the Foreign Office for assistance and replies from the China consuls are collected in Kew, Misc. Reports, 4.4, China, Foods, Medicines, \& Woods, 1869-1914; Misc. Reports, 4.4, China, Economic Products, I; Misc. Reports, 4.4, China, Economic Products, II; Misc. Reports 4.4, China \& Tibet, Misc. 1861-1924; Misc. Reports, 4.4 China, Economic Products, Insect White Wax; Kew, Misc. Reports, China, Plant Collections, Cultural Products, etc. 1853-1914. 
every few years, sometimes more than once a year. This internal policy of the institutions had beneficial consequences for naturalists' networking, information collecting and fieldwork. It provided them with mobility, social contact and new fieldwork sites - a highly relevant condition at a time when the research focus was collecting data. During a single career, a consular officer could have been appointed (as was Robert Swinhoe) to ports as far apart as Tamsui in Taiwan and Chefoo in Shandong (north China), and several others in between. ${ }^{71}$ The Maritime Customs adopted very much the same programme. Every move meant an opportunity for working at a new field site, especially if the post was in a place then little known to science. ${ }^{72}$ Swinhoe amazed naturalists in Europe with the numerous zoological discoveries he made in Taiwan in the 1860s, hitherto a terra incognita to the Western scientific community. When he was a viceconsul there, he lived in a modest Chinese-style house at the port of Tamsui, northern Taiwan, whose entire foreign population amounted to four souls. ${ }^{73}$ There was little official business, and Swinhoe devoted much of his time to natural history. A couple of years later, he was removed to Takow, southern Taiwan, equally unknown to science. He made many more discoveries there. ${ }^{74}$

Frequent transfers also increased the social contact and private networking among the officers. In the course of his career, an officer could establish friendships with many colleagues who also moved from place to place, and could thereby forge an extensive network of correspondence across much of China proper. Many officers shared an office at one place or another at some points during their careers. Friendship was maintained through regular correspondence thereafter. Hence, although the British in China resided in towns and cities scattered widely apart - in some cases thousands of miles - theirs was actually a close-knit network with a few particularly concentrated communities like that in Shanghai. Because of this institutional formulation, an enthusiastic naturalist could influence quite a few of his colleagues, encouraging them to take up natural history or persuading them to collect specimens and information for him in different parts of China. The naturalists - be they sedentary like Henry Hance or restless like Robert Swinhoe had little difficulty in building networks of scientific information, which were further widened by the many Western journals and newspapers in China.

Those who acquired a reputation among Westerners in China for their expertise and achievements as naturalists saw specimens come to them from willing helpers. We have seen how Hance developed his scientific career by this means. He was not alone.

71 Philip B. Hall, 'Robert Swinhoe (1836-77), FRS, FZS, FRGS : a Victorian naturalist in Treaty Port China', The Geographical Journal (1987), 153, 37-47.

72 Not surprisingly, some transfers could work against natural historical research. William Hancock was posted to Hankow in 1890 and he complained that during 'fifteen years residence in China' he has never resided in 'a more uninteresting \& (botanically) unproductive region than Hankow'. Kew, Chinese and Japanese Letters, 151 (481). But at a time when so much of the flora and fauna of China remained unknown, new moves usually meant good opportunities.

73 Kew, Kew Collectors, Oldham, 1861-4, IV, ff. 33-6.

74 For Swinhoe's scientific research in Taiwan see Zhang Yuteng, 'Yingguo bowuxuejia Shiwenhou zai Taiwan de zilanshi diaocha jingguo ji xiangguan shiliao', (The natural historical research of British naturalists Swinhoe in Taiwan and related historical material), Taiwan shi yanjiu (1993), 1, 132-51. 
Known to his colleagues as one who neglected his wife for zoology, ${ }^{75}$ Swinhoe likewise received animals and information from many unexpected sources. Whenever and wherever a Briton in China got an unusual animal, he was likely to send it to Mr Swinhoe. A consular officer in Shanghai brought back from Japan a pair of 'cranes' for the garden of the Consulate, but the Japanese newcomers turned out to be aggressive and bullied the other cranes already there. The wrongdoing pair was immediately banished from the garden and dispatched to Swinhoe, who found them to be a new species of stork. ${ }^{76}$ The senders perhaps needed some encouragement, and that could be easily done by naming the animals or plants after them. Swinhoe asked Henry Kopsch of the Chinese Customs to acquire specimens of a deer seen in his district and promised to name the deer after him if it turned out to be new. ${ }^{77}$ It was for a similar reason that William Gregory, a vice-consul, took great trouble to send Swinhoe 'an enormous Pipe Fish' from Taiwan. ${ }^{78}$

However, the naturalists' duties as government officials also set limits on their natural historical research. Lack of time seemed to be a common problem. The officials were supposed to be in office from nine to four except Sundays, and their workload could be heavy during certain times of the year. Complaints about their workload as government officers occurred from time to time in the naturalists' letters to scientific friends in Europe. After explaining to Thiselton-Dyer the many official dispatches he had to write, a consul speculated that HM officials in China had more routine office work than did their colleagues in Britain. ${ }^{79}$ Bound to the office, they could not do fieldwork and study natural history as much as they liked to, so many of them employed native collectors. Of course, the workload was contingent upon the officials' positions and locations. Some places were less busy than others. By the middle of the nineteenth century, the glorious days of Whampoa as a port were long gone, and Hance had plenty of time for botany. The success of Swinhoe and Henry tell a similar story.

Collecting data about economic botany occupied an important place in the naturalists' research, and they often had to rely on the local Chinese - magistrates, merchants and so on - for specimens and information, either through official channels or personal connections. The naturalists' positions as government officials provided them with status, authority and respectability, all of which facilitated their scientific enquiries. Chinese officials did not necessarily like Western government agents, but they were usually polite towards them and were willing to offer assistance to their enquiries as a friendly gesture. This kind of social intercourse in everyday life impinged only indirectly on Western imperial domination; it mainly followed the tradition of social etiquette between Chinese and British officials. Curious about whether the Manchurian tiger was a new species,

75 Brunner, Fairbank and Smith, Robert Hart and China's Early Modernization, op. cit. (53), 256.

76 Robert Swinhoe, 'On the White Stork of Japan', Proceedings of the Zoological Society (1873), 512-14.

77 Robert Swinhoe, 'On Chinese deer, with the description of an apparently new species', Proceedings of the Zoological Society (1873), 574. Kopsch was also similarly rewarded for sending Swinhoe bird specimens. See e.g. R. Swinhoe, 'On a new species of Nettapus (Cotton-Teal) from the River Yangtze, China', Annals and Magazines of Natural History (1873), sr. 4, 11, 15-17.

78 NHML, Z. Keeper's Archives, 1.8, Letters, 1858-75, SM-Z, No. 284.

79 Kew, Chinese and Japanese Letters, 151 (138), (142-3). 
Swinhoe secured a skull through the help of a Chinese governor..$^{80}$ On another occasion, he procured the skin of a rare bear 'through the civility of a high mandarin' ${ }^{81}$ Conversely, the animals that Swinhoe acquired by various means for zoological research invited requests from Chinese officials for the parts that were valuable in Chinese medicine. When he was in Taiwan, for example, he once acquired a mountain goat, and the 'high mandarin of the town begged the blood of this animal of me, and esteemed the gift a great favour'. ${ }^{82}$

For certain types of investigation, the Customs officers occupied a unique position because their duties required them to inspect the trade goods that trafficked through the ports. They had the opportunities of collecting information about particular vegetable products and medicinals, identifying the plants and finding out their origins. In addition, they had ready access to the Chinese who traded or manufactured these goods and who possessed first-hand information about the drugs, spices, vegetable oils, indigo plants and other items of economic botany. As a Customs officer in Canton, E. C. Bowra, 'whose position gives him great advantages in inquiries of this nature', procured for Hance a living specimen of the China root, a drug whose source Hance 'had long been anxious to ascertain'. ${ }^{83}$ Keenly aware of these conditions, Bretschneider, an authority on Chinese materia medica, urged the Customs officers to make enquiries of this nature and wrote an essay describing dozens of important vegetable products that needed further investigation. ${ }^{84}$ Admittedly, only a minority of the Customs officers knew enough about natural history to carry out in-depth scientific research, and most of them had to be satisfied with gathering specimens and information. Bretschneider criticized the many factual errors - particularly misidentifications of plants, drugs and so on-contained in the research reports on silk and materia medica issued by the Chinese Customs. ${ }^{85}$ His complaints should be taken as regrets over missed opportunities, however, because he himself frequently consulted the very studies he criticized in his research.

\section{Missionary and commercial institutions}

Although the majority of British naturalists in China were consular or Customs officers, there were also a number of missionaries notable for their exertions in natural history. Compared with Catholic (especially French) missionaries, Protestant missionaries in

80 George Busk, 'Notes on the cranial and dental characters of the northern and southern tigers and leopards of China as affording marks of their specific distribution', Proceedings of the Zoological Society (1874), 146-50.

81 Robert Swinhoe, 'On the mammals of the island of Formosa', Proceedings of the Zoological Society (1862), 347-65, 351.

82 Swinhoe, op. cit. (81), 362.

83 Henry Hance, 'On the source of the China root of commerce', The Journal of Botany, British and Foreign (i.e. Seemann’s Journal of Botany) (1872), 10, 102-3.

84 E. Bretschneider, Notes on Some Botanical Questions Connected with the Export Trade of China, Peking, 1880.

85 E. Bretschneider, 'Botanicon Sinicum: notes on Chinese botany from native and western sources, Part III', Journal of the North China Branch of the Royal Asiatic Society (1895), 29, 11-12; idem, On Chinese Silkworm Trees, Peking, 1881,1-2. See also idem, op. cit. (84), 1. 
China, mostly British and American, contributed little to natural history. The achievements of several French missionaries in China during this period attracted full attention of the scientific communities in Europe - for example, the celebrated zoologist Armand David, the conchologist Pierre Heude and the botanic collector Jean Marie Delavay. ${ }^{86}$ No Protestant missionaries accomplished half as much as they did. The marked difference between the Protestant and the Catholic missionaries' achievements in natural history resulted from their different approaches to missionary work. Catholic missionaries had long established themselves in the interior of China and maintained an extensive network across the Chinese Empire. The members were spread out and stationed in their designated places for decades, dressed and living as the natives did. They had unique access to western and south-western China, including Yunnan and the Sichuan-Tibet border, where the flora and fauna were rich and peculiar. The French also retained some elements of the early Jesuit approach in China, which emphasized Western achievements in science, and they established two museums, respectively in Beijing and Xujiahui, near Shanghai. Much of David's and Heude's scientific research was associated with these museums. ${ }^{87}$

The Protestant missionaries, on the other hand, were usually married and accompanied by their families. Their educational backgrounds were highly uneven. They stayed in coastal cities, kept their Western lifestyle, and devoted their attention to the urban and suburban poor. ${ }^{88}$ The movement of the China Inland Mission, which aimed at extending Protestant missionary work into the interior, accelerated only in the closing decades of the nineteenth century. ${ }^{89}$ Confined to the cities, the Protestant missionaries did not have good fieldwork sites nearby. Besides, the treaty ports had been the places most researched by Western naturalists, so it was difficult to find novelties in their vicinities. 'It is not surprising that English missionaries have done so little for the collection of Natural History from China ...', a Catholic missionary explained, 'they are mostly confined to towns, having residences there ${ }^{90}{ }^{90}$

It was a fair comment, but one cannot therefore infer that Protestant missionaries in China had no interest in, or simply ignored, natural history. A number of them D. J. McGowan, B. C. Henry, S. Wells Williams, Alexander Williamson, John Ross, John Chalmers, Walter Medhurst, Sr and Ernst Faber, for example - collected for scientific institutions, such as Kew Gardens, and for their scientific friends in China, notably Henry Hance. ${ }^{91}$ Some of them, like John Ross, travelled for missionary work and

86 Biographic information about these and many other French missionaries can be found in Bretschneider, op. cit. (33), 824-929.

87 On the Xujiahui (i.e. Zikawei or Sicawei) station, see Lewis Pyenson, Civilizing Mission: Exact Science and French Overseas Expansion, 1830-1940, Baltimore, 1993, 155-206. It focuses on the observatory there.

88 Medhurst, op. cit. (1), 32-5; Armand David, Abbé David's Diary, Cambridge, MA, 1949, 193.

89 On the China Inland Mission see Leslie T. Lyall, A Passion for the Impossible: The China Inland Mission, 1865-1965, London, 1965, and A. J. Broomhall, Hudson Taylor and China's Open Century, 7 vols., London, 1981-9.

90 NHML, Curator of Mammals, Correspondence, DF232/5, No. 234-5.

91 Of them Williams, McGowan, and Henry were American; Faber, German. The others were British. Basic biographic information about them can be found in Bretschneider, op. cit. (33). 
collected along the way. ${ }^{92}$ A few studied Chinese materia medica, notably F. Porter Smith, particularly because the Protestant missionaries were very active in medical missionary work and had founded several hospitals in China. ${ }^{93}$

The largest group of British residents in China were neither diplomats nor missionaries, but merchants (including engineers and other professionals working in the area of commerce). Despite its size, this group was less visible in natural history than were the diplomats and the missionaries. This difference was, above all, a consequence of the overall low interest in natural history among the merchant class. But there were also external factors. The vast majority of the merchants resided in major treaty ports, for obvious reasons. Big business could be found only in big cities. Like many missionaries, they flocked to geographic locations unfavourable to fieldwork of any kind. However, a few did turn their attention to natural history. Francis Forbes, head of a large American company, took up botany and collecting. ${ }^{94}$ John Charles Bowring, son of Sir John, the savant Governor of Hong Kong, pursued a mercantile career and amassed a large collection of insects. ${ }^{95}$ Thomas Kingsmill, engineer and merchant, was one of the few British geologists in China and made good collections of fossils, many of which had been found at drugstores in Shanghai. ${ }^{96}$ The merchants made their greatest impact upon zoology, in part because hunting was a highly popular pursuit among Western residents in China. Together with J. D. D. La Touche, a Customs commissioner, the merchants Frederic William Styan and Charles Boughey Rickett more than any other Britons filled the gap left by the retirement of Swinhoe. ${ }^{97}$ The merchants also sponsored geographical and geological investigations into China's natural resources, trade routes and market potential. The most notable attempt was Ferdinand von Richthofen's survey of China's mineral riches in the 1870s. Eager to assess the natural resources of different parts of China, Western (predominantly British) merchants in Shanghai employed Richthofen, a German geologist, to examine the geological formations and mineral, especially coal, deposits, and he travelled all over China proper, observing its geology and geography. ${ }^{\mathbf{9}}$

92 E.g. Kew, Chinese and Japanese Letters, 150 (338-9), (353-4), (572); 151 (916)-(918); J. G. Baker, 'A contribution to the flora of northern China', Journal of the Linnean Society (1880), 42, 375-90; Alexander Williamson, Journeys in North China, Manchuria, and Eastern Mongolia, 2 vols., London, 1870, ii, 'Appendix D. List of plants from Shan-tung, collected by the Rev. A. Williamson'; B. C. Henry, Ling-Nam or Interior Views of Southern China, London, 1886, 123-4; Bretschneider, op. cit. (33), 954-9.

93 F. Porter Smith, Contributions towards the Materia Medica and Natural History of China. For the Use of Medical Missionaries and Native Medical Students, Shanghai, 1871.

94 Bretschneider, op. cit. (33), 720-3.

95 James Troyer, 'John Charles Bowring (1821-1893): contributions of a merchant to natural history', Archives of Natural History (1982), 10, 515-29. See also Anon., The History of the Collections Contained in the Natural History Departments of the British Museum, 3 vols., London, 1904-12, ii, 581.

96 George Lanning, 'Thos. W. Kingsmill', Journal of the North China Branch of the Royal Asiatic Society (1910), 41, 116-18; Robert Swinhoe, 'Zoological notes of a journey from Canton to Peking and Kalgan', Proceedings of the Zoological Society (1870), 427-51, 428-9.

97 Barbara and Richard Mearns, The Bird Collectors, San Diego, 1997, 140-1; C. B. R., untitled obituary of J. D. D. La Touche, Ibis (1935), 5, 210, 889-90.

98 Ferdinand von Richthofen, Letters to the Shanghai General Chamber of Commerce, Shanghai, 1875. Wang Gen-yuan and Michel Gert, 'The German scholar Ferdinand von Richthofen and geology in China', in Interchange of Geoscience Ideas Between the East and the West (Proceedings of the XVth International Symposium of INHIGEO), Wuhan, 1991, 47-54. 
Trade sustained the flourishing and largely mercantile British communities in China, and the major trade items were products of animal or plant origins. The successive curators of the Shanghai Museum, a natural history museum founded in 1874 and affiliated with the North China Branch of the Royal Asiatic Society, all noted the importance of enlarging its collection of products of nature and artefacts in trade. ${ }^{99}$ Later in the century, a plan for a 'Trade and Commerce Museum' was presented. ${ }^{100}$ The museum would display artefacts and natural products in trade and would style itself as a window to the China trade. The museum would therefore serve commercial, scientific and educational purposes. But for an inherent conflict of interests, British merchants in China might have shown more interest in investigating the 'secrets' of many Chinese products of vegetable or animal origins. As traders, they naturally wanted to have a monopoly on supplying Western markets with these products, and letting the Chinese keep the supply actually worked better for them than letting it shift to the colonies. The development of tea production in India would eventually damage the profits of British tea traders in China. Consuls, Customs officers and missionaries, on the other hand, had relatively little personal investment at stake and freely enquired into economic botany and related matters. Even a high-minded taxonomist like Henry Hance plunged himself into intensive research on wild silkworms, matting and other subjects in economic botany. ${ }^{101}$ Rutherford Alcock of the Consular Service not only procured David's deer, a recent discovery, for the Zoological Society of London, but also sent them Chinese sheep, noted for their amazing reproductive power, in the hope of introducing them into Britain. ${ }^{102}$

Although the diplomatic, the missionary, the commercial and the botanical establishments discussed above differed in their manifested purposes, they shared important similarities. They were all involved in collecting, processing and distributing information about China. The Consular Service and the Maritime Customs were respectively British and Chinese government agencies dealing with diplomatic relations (defined broadly) and trade. They constantly kept their eyes on the political developments, social change and economic opportunities in China. The missionary societies studied the Chinese with the aim of converting them. The merchants eagerly collected information about trade routes, potential new markets and profitable export products. The Hong Kong Botanic Gardens, though hampered by bureaucratic obstacles, struggled to achieve the research goals that Joseph Hooker laid out for it - investigating the flora of China and the origins of Chinese vegetable products. As the major functions of these

99 See e.g. A. A. Fauvel, 'Shanghai Museum, report of the curator for the year 1878', Journal of the North China Branch of the Royal Asiatic Society (1878), n.s., 13, pp. xvii-xviii; D. C. Jansen, 'Shanghai Museum, report of the curator for the year 1880', Journal of the North China Branch of the Royal Asiatic Society (1880), n.s., 15, pp. xxiii-xxiv.

100 H. B. Morse, 'Report of the council on the proposed trade and commerce museum', Journal of the North China Branch of the Royal Asiatic Society (1888), n.s., 23, 49-53.

101 E.g. Henry Hance, 'On silk-worm oaks', China Review (1877), 6, 207-8; idem, 'On the sources of the “China Matting”'of commerce', Journal of Botany (1879), n.s., 8, 99-105; 'On a new Chinese Caryota', Journal of Botany (1879), n.s., 8, 174-7.

102 P. L. Sclater, Guide to the Gardens of the Zoological Society of London, London, 1872, 39; A. D. Bartlett, 'Description of Chinese sheep sent to H. R. H. Prince Albert by Rutherford Alcock', Proceedings of the Zoological Society (1857), 104-7. 
establishments included collecting, analysing, circulating and distributing information information about China, about its people, culture, society, commerce, geography and natural history - they developed social networks and an infrastructure to carry out the tasks. Reliable channels of communication carried private correspondence as well as official dispatches fast and wide. Thus equipped, these institutions operated independently or together to gather relevant information and produce factual knowledge about China. Enquiries into China's natural history constituted part of this enterprise of 'surveying' China.

\section{Scientific imperialism and factual knowledge}

Research into China's natural history usually involved the natives. In pursuing fieldwork, for example, the naturalists typically hired native guides and collectors, and invariably sought assistance from the local inhabitants, whose familiarity with the local flora and fauna was unmatched. Similarly, for enquiries into economic botany, contact with the natives was almost inevitable. The natives controlled the supply of trade items of animal and plant origins. They knew what plants or animals the products were made of and where they could be found. The investigations, moreover, required more than identifying the origins of the products. It was also necessary to find out the methods of processing and manufacturing them. Since the Chinese occupied certain critical links in the networks of information, one of the main tasks of the naturalists was to secure their cooperation.

One of the most significant cases of acquiring indigenous knowledge of manufacturing plant products was probably Robert Fortune's mission to procure Chinese tea manufacturers for the East India Company's tea plantations in India. While in the tea districts of China, Fortune had no difficulty in obtaining permission to observe the process of manufacturing tea on many occasions, and he wrote down the details as carefully as he could. Yet much of the skills and techniques could be mastered only by years of experience and practice; this kind of tacit knowledge easily eluded even the most attentive observer. With the help of the Consular Service, Fortune succeeded in persuading quite a few Chinese tea manufacturers, bringing with them the implements of their trade, to help develop tea plantations in India. It proved to be a shortcut to successful technology transfer. The tea trees transplanted from China perished in India, and it was native wild tea trees and hybrid types that finally made up the output of Indian teas, but the knowledge of manufacturing tea had come from Chinese immigrants in India and the tea manufacturers who went to the tea plantations. ${ }^{103}$ To give another example, Kew Gardens was keen to find out the origin of an unusual kind of 'camphor oil' trading by way of Hainan, an island off the southern coast of China. There had been confusion as to its origin, for it was extremely difficult to identify the plant from the final product. Consul M. F. A. Fraser in Hainan took advantage of his position and asked around

103 Robert Fortune's endeavours for tea hunting were described in A Journey to the Tea Countries of China, London, 1987 [1852] and A Residence among the Chinese: Inland, on the Coast, and at Sea, London, 1857; Percival Griffiths, The History of the Indian Tea Industry, London, 1967, 34-58, 64-9, 78-81, 90. 
among the Chinese for information. Some Chinese traders from Guangxi, the province where the oil was produced, were familiar not only with the plant in question, but also with the method of distilling the oil. They pointed out to Fraser the correct plant, and upon request, they explained the process of manufacturing the oil. ${ }^{104}$

There was always the possibility of exposing oneself to commercial competition by sharing one's trade secrets with others, and the Chinese were not oblivious to that simple fact. The naturalists' impressions of their informants differed, but many cited the long-standing belief in the Chinese suspicion and jealousy of foreigners. ${ }^{105}$ Whether it was their own imagination or not, the naturalists often felt that the Chinese withheld vital data. When the seeds they acquired from the Chinese did not germinate, they suspected the Chinese of having boiled, baked or poisoned them to protect their profits in trade. This notion of Chinese bad faith was widely held by the British. In a letter to the Gardener's Chronicle, the botanist John Henslow thundered, 'I have more than once received seeds from China in these little jars, but scarcely any of them germinated, and I believe it is a custom with the Chinese to scald the seeds they sell to barbarians!'106 Determined to solve the puzzle of the Chinese seeds, Fortune called upon Aching, a nurseryman in Canton who traded in large volumes with the Westerners, for a demonstration of how seeds were packed for export. Poor old Aching had 'got a bad name' among the British over the years because the seeds he sold them often did not germinate. ${ }^{\mathbf{1 0 7}}$ After examining the procedure, however, Fortune decided to give the Chinese some credit for honesty: 'The Chinese are certainly bad enough, but, like other rogues, they are sometimes painted worse than they really are' ${ }^{108}$ In the end, he attributed the problem to long-distance transport. Nevertheless, doubts continued. After several failures in growing the star anise, a plant of commercial value, in the 1870s, Hance was convinced that the Chinese baked the seeds before parting with them. But his friend Ford found out later that the same kind of seed sent to him by the French in Tonkin did not germinate either. Ford then concluded that the seeds easily lost their vitality. ${ }^{\mathbf{1 0 9}}$

If these examples suggest the naturalists' inclination to distrust the Chinese, the suspicion was probably mutual. It should surprise no one that some Chinese might have assertively guarded their profits. In 1882 Ford travelled a long way to an area where valuable cassia trees grew, only to learn that the Chinese there would not let him have more than a few living plants. They were reluctant to share their moneymaking trees with foreigners. Ford later must have congratulated himself on his tactics. $\mathrm{He}$ sent one of his Chinese collectors, disguised as a dealer, into the cassia district further inland to 'buy up all the young plants in the nurseries', before the natives discovered his true identity. ${ }^{110}$ During his journeys in China, Robert Fortune came across a 'mosquito tobacco' that proved to be wonderfully effective in warding off the pests, so

104 Kew, Misc. Reports, 4.4, China, Economic Products, II, ff. 284-5, 286-8, 289-95.

105 Kew, Chinese and Japanese Letters, 150 (285).

106 Gardeners' Chronicles, 22 June 1844, 405.

107 Robert Fortune, Three Years' Wanderings in the Northern Provinces of China, London, 1847, 55.

108 Fortune, Journey to the Tea Countries, op. cit. (103), 130-2. Fortune either recounted the same incidents twice or watched Aching pack seeds again in this second journey.

109 Public Records Office (Hong Kong), CO 129/202, 129/206.

110 Henry, op. cit. (92), 102. See also Kew, Chinese and Japanese Letters, 150 (417-18). 
he intended to find out the ingredients of the drug. He called upon a shop making and selling the item, prying about the ingredients, their relative proportions, the process of manufacturing and so on, but received only evasive answers once his intention became all too clear. Fortune was not ready to give up. He put the matter in the hands of his Chinese associates, who finally obtained the valuable information after months of insinuation. ${ }^{111}$

Whether these and similar accounts were reliable or not, they shared a common strategy of representation used by the naturalists in telling about their encounters with the natives. If the Chinese tried to guard their profits or use tactics, they were mean, jealous and cunning. If the British themselves were doing that, even breaking the laws of the natives, they were portrayed as smart, adventurous heroes outwitting the conceited natives. Robert Fortune's highly popular travel books were full of episodes of this kind. This kind of orientalist representation allowed the naturalists to justify their otherwise less than honourable behaviours. The narrative was slightly complicated by the presence of the Chinese 'helpers', but they were conveniently reduced to passive figures in compliance. In this type of narrative, the Chinese were either deprived of their motives and initiatives or, if they displayed them, were cast as rogues or troublemakers. This is not to deny that Orientalism as a historical phenomenon could be rich in connotation and that European representations of the Orient were not as uniform and static as portrayed by some scholars. ${ }^{112}$ It is probably true, too, that China occupied a somewhat special place in Western representations of other civilizations. Nevertheless, what we have just identified was certainly a principal way of representing non-Western peoples and civilizations, one which depended heavily on the language of 'othering' and which prevailed in certain kinds of narrative.

In addition to noticing this strategy of representation, one might also be tempted to interpret the actions of the Chinese within the postcolonial model of resistance against imperial domination. ${ }^{113}$ The Chinese were using 'weapons of the weak' (e.g. 'sabotaging' the seeds, withholding information) to resist the dominating Western imperial power. ${ }^{114}$ This reading is based on a model of power relations developed to interpret colonial experiences and, valuable as it is, it works less well in the context of China, which maintained much of its political autonomy despite pressures from the West. Indeed, the model oversimplifies even the historical agency of the natives in colonial context. It is

111 Fortune, Residence among the Chinese, op. cit. (103), 109-15.

112 On this point, I agree with John M. MacKenzie, Orientalism: History, Theory and the Arts, Manchester, 1995.

113 My thinking has involved, among others, the following works: Gyan Prakash (ed.), After Colonialism: Imperial Histories and Postcolonial Displacements, Princeton, 1995 ; Edward Said, Culture and Imperialism, New York, 1993, Chapter 3; Homi K. Bhabha, The Location of Culture, London, 1994, especially Chapters 5 and 6. See also 'Introduction' to Nicholas Dirks, Geoff Eley and Sherry Ortner (eds.), Culture/Power/History: A Reader in Contemporary Social Theory, Princeton, 1994, 3-45; Sherry Ortner, 'Resistance and the problem of ethnographic refusal', The Historical Turn in the Human Sciences (ed. Terence J. McDonald), Ann Arbor, 1996, 304.

114 I borrowed the phrase from James C. Scott, Weapons of the Weak: Everyday Forms of Peasant Resistance, New Haven, 1985. See also his wide-ranging Domination and the Arts of Resistance: Hidden Transcripts, New Haven, 1990. It should be noted that Scott is primarily concerned with, so to speak, power relations between social classes. 
of course necessary to take into account the order of power relations that Western imperialism tried to impose on the colonies and, in the present case, China by means of military force, economic aggression and diplomatic pressure. Yet it is equally important to ask how the Chinese might have regarded the encounters in economic botany, for they, too, were agents of historical process and took actions according to their interpretations of events. What did the Westerners' insistent inquiries mean to them ? ${ }^{115}$ Without direct evidence, one can only conjecture. In all likelihood, however, some Chinese did refuse to share their trade secrets with Westerners (and, no doubt, many other Chinese as well) for fear of creating business competitors who would hurt their trade. They probably did not see the situation in terms of imperial domination and native resistance but, rather, followed their business savvy.

Although suspicion and jealousy were typically cited by the naturalists as accounting for the difficulty of procuring reliable information from the Chinese, they accused the Chinese of another, even more fundamental, 'sin' against the pursuit of truth. They claimed that the Chinese knew not the value of facts. Few of the faults of the Chinese ranked as high in the Western eyes as their (alleged) carelessness about 'facts'. It was considered to be one of the conclusive proofs of Chinese sloppiness, ignorance and backwardness. It also particularly annoyed the naturalists, who took pride in their relentless pursuit of 'objective' data. Robert Fortune criticized the Chinese on this point only three pages into his first travel book on China: 'I have been often much annoyed with this propensity of theirs [i.e. carelessness about correct information] during my travels in the country'. ${ }^{116}$ Fortune was by no means the most unsympathetic of all Western commentators on the Chinese. But he repeated the same point again and again throughout all his books on his China travels: 'one is very apt to be misled by the Chinese; not, perhaps, so much intentionally as from ignorance or carelessness as to whether the information given be correct or otherwise'. ${ }^{117}$ One can almost imagine Mr Gradgrind from Dickens's Hard Times shouting at a Chinese, 'Now, what I want is, Facts ... Stick to Facts, sir!'

Scholars have studied the formation of the modern conception of 'facts' and described how this belief in factual knowledge gradually attained an indisputable cultural authority in early modern Europe. ${ }^{118}$ Westerners in China had no doubt about the superiority of this knowledge tradition over whatever the muddle-headed Chinese had. The best example of this attitude may be found in the management of the Chinese Customs, which was a Western-style institution, headed and run by Westerners, but belonging to the Chinese government. The British insisted on having full control over the management

115 I have been influenced by Sherry B. Ortner, 'Thick resistance: death and the cultural construction of agency in Himalayan mountaineering', Representations (1997), 59, 135-62; Lydia Liu, Translingual Practice: Literature, National Culture, and Translated Modernity - China, 1900-1937, Stanford, 1995.

116 Fortune, op. cit. (107), 3.

117 Fortune, A Residence among the Chinese, op. cit. (103), 206.

118 For example, Steven Shapin, A Social History of Truth, Chicago, 1994; Lorraine Daston, 'The moral economy of science', Osiris (1995), 10, 3-24; idem, 'Baconian facts, academic civility, and the prehistory of objectivity', Annals of Scholarship (1991), 8, 337-64; Mary Poovey, A History of the Modern Fact: Problems of Knowledge in the Sciences of Wealth and Society, Chicago, 1998. 
of the establishment partly on the belief (and pretense) that the Chinese could not do it well. Robert Hart, Inspector-General of the institution, instructed his Office to publish a series of impressively detailed statistical studies on important items going through the ports, including opium and Chinese drugs. In the same manner, they also put out volumes of scientific studies on silk, fisheries, public health and so on. These volumes were compilations of reports sent by the officers from every treaty port to the headquarters. The officers evidently had made diligent efforts to collect, classify and analyse the data. Claims of factual accuracy were manifest in the form and content of these publications; multiple-column tables and statistics, transplanted from Western practice, filled many of the volumes. ${ }^{119}$

It is worth noting that the Chinese had their own tradition of gathering political, economic and geographic data, and that they, too, published them in official format. The fangzhi or gazetteer, an official publication issued by local governments, typically included 'facts' of local history, geography and natural history, and numerical data of population and revenue. Not only did Westerners in China know of them, they actually used them, mining them for information. However, they found fundamental flaws in the Chinese attitude towards facts. 'My experience of the Chinese Empire teaches me', remarked Thomas T. Meadows, HM Consul and a prominent sinologist, 'that it is impossible to obtain from Chinese sources materials for [statistical research]'. ${ }^{120}$ They were convinced that while the Westerners pursued objective, empirical knowledge, the Chinese inevitably mixed up facts with fantasies, myths and all sorts of false information. The Chinese loved grotesques, and they were ridiculously unobservant and credulous. They could not tell facts from tall tales and they did not care. Thus this orientalist discourse defined a Chinese otherness - their inability to appreciate the unique value of 'facts'. In their general works on China, both John Davis and S. Wells Williams agreed that 'the general state of sciences' among the Chinese reached at best the level in Europe 'previous to the adoption of the inductive mode of investigation'. ${ }^{121}$

As a result, the naturalists believed that their endeavours of investigating the natural history of China and collecting information about economic botany went beyond seeking profits for Britain. Exploring the natural resources of China was justified on the grounds of mutual benefits. Their rationalization may be summarized as follows. The ignorant and unscientific Chinese could not take full advantage of their natural resources, and they suffered from that. Worse, their instinctual jealousy blinded them from seeing how they themselves could benefit from letting the 'enlightened' Westerners utilize the

119 See n. 65.

120 Thomas Taylor Meadows, 'Report on the consular district of New-Chuang, with the particular reference to its commercial capabilities', 1. The report is collected in Commercial Reports from Her Majesty's Consuls in China for the Year 1862, London, 1864. See also Theodore M. Porter, The Rise of Statistical Thinking, 1820-1900, Princeton, 1986; Poovey, op. cit. (118), Chapters 6 and 7.

121 S. Wells Williams, The Middle Kingdom: A Survey of the Geography, Government, Literature, Social Life, Arts, and History of the Chinese Empire and Its Inhabitants, 2 vols., New York, 1913 [1882], ii, 65; John Davis, China: A General Description of that Empire and Its Inhabitants, revised edn., 2 vols., London, 1857, ii, 221. See also Michael Adas, Machines as the Measure of Men: Science, Technology, and Ideologies of Western Dominance, Ithaca, NY, 1989, 338-42. 
natural riches to everyone's advantage. The Chinese were foolish and selfish not to see the light and embrace this high-minded goal. And although they sometimes had ingenious products and means of manufacturing them, they lacked the knowledge above all, scientific knowledge - to improve them. Hence the naturalists were convinced that they had the right and responsibility to obtain the knowledge of not only China's natural history but also its animal and plant products of economic value. In the hands of the Chinese, they believed, the treasures would be wasted. This logic of paternal imperialism underlined much of the naturalists' conviction that they ought to have access to the information they needed, though, of course, there was also utter arrogance and sheer greed.

\section{Conclusion}

The activities of natural history in the imperial context - mapping, collecting, ordering, classifying, naming and so on - represented more than matter-of-fact scientific research. It also reflected an aggressive expansion of cognitive territory defined in particular cultural terms. The 'discovery' of a new bird or plant - classifying it, placing it in the Linnaean taxonomy, describing it in strict scientific Latin, representing it in Western pictorial techniques, turning living samples of it into material embodiments of abstract scientific concepts and specialized terminology, configuring its global distribution in rigorously defined diagrams, etc. - privileged a specific way of defining nature, facts and knowledge. In the nineteenth century scientific expeditions, whose core concepts and activities involved collecting, measuring, mapping and travelling, and whose ultimate goal was to write the natural history of the globe with exhaustive comprehensiveness and precision, originated in part from a view of geography and nature coupled with European expansion and from an assumption of the right of 'objective' European scientists to travel and observe other continents of the world. This conviction of a right to know, a right that was ideally not restrained by human boundaries particularly, the boundaries drawn by the natives against European scientific researchers - derived its authority partly from a belief in the universal validity of factual knowledge.

Thus one of the major components of scientific imperialism was the ideology and practice of collecting information and producing knowledge - knowledge that claimed to be factual, objective, scientific and definitive - about other parts of the world. It asserted an epistemological authority and it pointed towards an ideal and belief of bringing the natural world, regardless of national and other human boundaries, under a viewpoint from a high altitude of truth. British naturalists in China participated in building this empire of information, empire of knowledge. Another major component of this empire of information was that the knowledge it produced was not simply 'objective' but also useful. For the naturalists, taking possession of the data of China's natural history and economic botany was in the interest of the natives as well as the Europeans. They deemed that they could produce useful, scientific knowledge from the information and that the knowledge - whether it was geology, economic botany or some other science - would eventually bring benefits to the Chinese. Possessing, in 
this view, would prove to be a generous way of giving. ${ }^{122}$ The natives' wish had no place in this grand vision of scientific commonweal.

Given the importance of information collecting, it was no accident that Joseph Hooker insisted that 'exploration' and 'correspondence' be a crucial part of Charles Ford's official duties as Superintendent of the Hong Kong Botanic Gardens. Both activities were to collect data - information and specimens. Similarly, it was only natural that Hooker instructed Ford to transform the Gardens into 'the channel of communication' of botanical matters on China and that he urged Ford to 'enlist the co-operation' of people who resided and travelled in the China region. This vision was only partially realized because of the conflicts between British imperial institutions and, more importantly, the external political situations. The network of colonial botanical gardens could not easily ramify in a non-colonial region. Yet British scientific imperialism did not stop at the colonial boundaries, but expanded along the legal, political and economic apparatuses of informal empire, in whose shadow Victorian naturalists in China developed information technologies, including extensive and efficient networks, and carried out their research.

122 I have benefited from the insights in Mary Louise Pratt, The Imperial Eye: Travel Writing and Transculturation, London, 1992, and Stephen Greenblatt's Marvelous Possessions: The Wonder of the New World, Chicago, 1991. 